\title{
The Function of a Conjunction: Inclusivist or Exclusivist Strategies in Ezra 6.19-21 and Nehemiah 10.29-30?*
}

\author{
MATTHEW THIESSEN \\ Duke University, Department of Religion, Durham, NC 27708, USA
}

\begin{abstract}
In spite of the genealogical exclusion of non-Israelites evidenced throughout Ezra-Nehemiah, numerous scholars find strategies of inclusivism within the work. In particular, Ezra 6.19-21 and Neh. 10.29-30 have been understood to envision the incorporation of outsiders into the Golah group. After surveying the evidence for exclusivism in Ezra-Nehemiah, this article presents an alternative reading of these specific passages by providing a different interpretation of the function of the waw. It is argued that, instead of intending to portray outsiders joining the Golah group, Ezra 6.19-21 and Neh. 10.29-30 describe the separation of the Golah group from the impurity of the nations.
\end{abstract}

Keywords: Ezra-Nehemiah, exclusivism, waw explicativum, Passover.

* I am thankful for the insightful comments made by Joel Marcus and Andrea di Giovanni on an earlier draft of this article. 


\section{Introduction}

Scholars of the early Second Temple Period have almost universally understood Ezra-Nehemiah to be promoting an exclusivistic definition of Israel. ${ }^{1}$ For instance, David Janzen states: 'The picture of the assembly as by nature ontologically different and exclusive of all who were not descended from the Babylonian exiles is, in some sense, the theme of Ezra-Nehemiah'. ${ }^{2}$ In contrast to this restrictive definition of Israel, most scholars believe that Ezra 6.19-21 and Neh. 10.29-30 evidence a more open and inclusive understanding of membership in the people of God, since both passages appear to portray the Golah group being joined by 'everyone who separated from (the impurity of) the peoples of the land(s)' (וכל הנבדל מטמאת גוי הארץ, Ezra 6.21; וכל הנבדל מעמי הארצות, Neh. 10.29). ${ }^{3}$ This disparity, as we shall see, is alleviated by a different way of translating the passages in question. In order to achieve this goal, I will provide a brief survey of passages within EzraNehemiah which demonstrate that the work functions with the belief that there is an ontological (or genealogical) distinction between Israel and the other nations. Then, I will reconsider previous translations and interpretations of Ezra 6.21, in order to show that an inclusivist understanding is not the only way to construe the passage. Finally, I will argue for an exclusivist reading of the passage that provides a more compelling account of how the verse both fits within its present context and relates to the broader theme of exclusion in Ezra-Nehemiah. While this analysis runs contrary to virtually all modern translations and interpretations, 1 Esdras may well provide early evidence for such a reading. If this explanation of Ezra 6.21 is indeed correct, then the same phrase in Neh. 10.29 ought to be translated similarly.

\section{Genealogical Exclusion in Ezra-Nehemiah}

The first instance of ontological/genealogical thought within Ezra-Nehemiah can be found in Ezra 2 (cf. Neh. 7), which contains the genealogies of those

1. One notable exception to this view is Hyam Maccoby, 'Holiness and Purity: The Holy People in Leviticus and Ezra-Nehemiah', in John F.A. Sawyer (ed.), Reading Leviticus: A Conversation with Mary Douglas (JSOTSup, 227; Sheffield: Sheffield Academic Press, 1996), pp. 153-70.

2. David Janzen, Witch-hunts, Purity and Social Boundaries: The Expulsion of the Foreign Women in Ezra 9-10 (JSOTSup, 350; Sheffield: Sheffield Academic Press, 2002), p. 90. Similarly, Saul M. Olyan, 'Purity Ideology in Ezra-Nehemiah as a Tool to Reconstitute the Community', JSJ 35 (2004), pp. 1-16 (1-2), states that the 'work's overriding concern [is] for self-definition and its establishment of a novel set of group boundaries distinguishing Judeans from others'.

3. Unless otherwise stated, all translations are my own. 
who returned to Judah from Babylon. ${ }^{4}$ The purpose of the genealogies is clarified by the inclusion of a list of a number of families who did not have records establishing their ancestry (Ezra 2.59-63; Neh. 7.61-65): three lay clans (the sons of Delaiah, the sons of Tobiah, and the sons of Nekoda), as well as three priestly clans (the sons of Habaiah, the sons of Hakkoz, and the sons of Barzillai). These families were not able to prove their fathers' houses, nor their descent, which, as the narrator informs the reader, meant that they could not demonstrate whether they belonged to Israel (אם מישראל הם, Ezra 2.59; Neh. 7.61). The significance of this statement is that it shows that the narrator equates descent with belonging to Israel. According to Ezra 2 and Nehemiah 7, genealogical descent is the defining characteristic of Israel.

Although the reader is not told what consequences resulted for the three lay families, the fact that the priests were excluded from the priesthood due to uncertainty surrounding their ancestry suggests that the lay families may also have been excluded from some of the privileges afforded to lay Israelites. ${ }^{5}$ So long as these lay families could not demonstrate their descent it is probable that they could not intermarry with those of impeccable genealogy; if Ezra and Nehemiah required that Israelite men divorce their foreign wives, would proven Israelites take the risk of marrying those who might turn out to be of foreign descent? While it appears that some of these families were eventually incorporated into Israel, ${ }^{6}$ the mention of families who are without proof of their ancestry testifies to the overwhelming significance accorded genealogical descent by Ezra-Nehemiah - something of such importance that 'great care was taken of family records, perhaps especially during the exile when the other

4. On the relationship between the two genealogies and the question of priority, see D.J.A. Clines, Ezra, Nehemiah, Esther (NCBC; Grand Rapids: Eerdmans, 1984), pp. 44-45, and H.G.M. Williamson, Ezra, Nehemiah (WBC, 16; Waco: Word Books, 1985), pp. 28-32. While the present discussion focuses primarily on Ezra 2, Tamara C. Eskenazi, In an Age of Prose: A Literary Approach to Ezra-Nehemiah (SBLMS, 36; Atlanta: Scholars Press, 1988), pp. 181-83, is correct to note the importance of both genealogies in that they form an inclusio around the heart of the book.

5. As Clines, Ezra, p. 58, notes, 'unless a line of descent reaching back to one of the certified phratry-founders could be produced by a pater familias, full enjoyment of the rights and privileges of members of the community could not be had'. Contra Jacob M. Myers, Ezra-Nehemiah: Introduction, Translation, and Notes (AB, 14; Garden City: Doubleday, 1965), p. 20, and Williamson, Ezra, Nehemiah, pp. 36-37, the latter of whom states that "while we have no knowledge of what happened to them eventually, the fact that they are listed here with their numbers indicates that while they awaited clarification of their status, they were treated in the same way as the earlier families'.

6. Neh. 7.63 suggests that Hakkoz's family was later reinstated since Meremoth ben Uriah was of the Hakkoz family yet also served as a priest (cf. Neh. 3.4; Ezra 8.33). In all likelihood, in the mind of the narrator the incorporation of Hakkoz did not occur in the face of evidence of foreign descent; rather, his proper descent was ascertained in some unspecified way. 
great guarantee of continuity, the land itself, was lost. This explains both the origin and the abundance of such lists at this period'. ${ }^{7}$

Confirmation that for Ezra-Nehemiah proper genealogical descent was constitutive of Israelite identity can be found in Ezra 4.1-3. The people of the land first approach Zerubbabel with the request that they too might help in the rebuilding of the Temple. According to their own self-description, they כבםם worship the same God in the same way as the returnees from Babylon (נדרוש לאלהיכם and have in fact sacrificed to him since the days of Esarhaddon (4.2). In response to this request, the leaders of the returnees state: 'There is nothing in common between you and us in building the house of

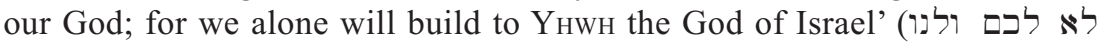
לבנות בית לאלהינו כי אנחנו יחד נבנה ליהוה אלהי ישראל 4.3). While the remainder of the chapter demonstrates that they are, in fact, Israel's enemies, in 4.1-3 there is only one indication of why this group could not help rebuild the Temple-their 'self-confessed foreign origin'. ${ }^{8}$ As Sara Japhet states, 'The view of Ezr.-Neh. on the question of identity is simple and uncomplicated, like many a dogmatic conviction. "Israelites" equal "returned exiles." Otherwise there are only foreigners in the land, no matter what their religious practice may be.' ${ }^{9}$ Despite their self-confessed fidelity to YHWH, the adversaries of Judah and Benjamin are excluded from the cultic apparatus because it is believed that they are in no way related to those who have returned from the Babylonian Exile.

One of the central texts used to demonstrate Ezra-Nehemiah's exclusivity with regard to those who were not genealogically Israelite is the story of the 'mass divorce' found in Ezra 9-10 and Neh. 13.23-30. ${ }^{10}$ In Ezra 9.1-2, the Golah officials approach Ezra, informing him that the people, priests, and Levites have not separated themselves (בדל) from the peoples of

7. Williamson, Ezra, Nehemiah, p. 36.

8. Williamson, Ezra, Nehemiah, p. 50. On the basis of 2 Kgs 17.24-34, Joseph Blenkinsopp, Ezra-Nehemiah: A Commentary (OTL; Philadelphia: Westminster Press, 1988), p. 107, and Myers, Ezra-Nehemiah, pp. 35-36, argue that this group was excluded because of syncretistic practices. This reason is not found in Ezra.

9. Sara Japhet, 'People and Land in the Restoration Period', in Georg Strecker (ed.), Das Land Israel in biblischer Zeit: Jerusalem-Symposium 1981 der Hebräischen Universität und der Georg-August-Universität (Göttinger Theologische Arbeiten, 25; Göttingen: Vandenhoeck \& Ruprecht, 1983), pp. 103-25 (116). See also Tamara C. Eskenazi and Eleanore P. Judd, 'Marriage to a Stranger in Ezra 9-10', in Tamara C. Eskenazi and Kent H. Richards (eds.), Second Temple Studies 2: Temple and Community in the Persian Period (JSOTSup, 175; Sheffield: JSOT Press, 1994), pp. 266-85 (269).

10. Janzen, Witch-hunts, p. 1. For a discussion of the possible economic and political motivations behind these divorces, see Harold C. Washington, 'The Strange Woman (אשה זרה/נכריה) of Proverbs 1-9 and Post-Exilic Judaean Society', in Eskenazi and Richards (eds.), Second Temple Studies 2, pp. 217-42. Since Ezra 9-10 and Neh. 13.2330 are in most respects quite similar, I will limit my discussion to the former passage. 
the lands - the Canaanites, the Hittites, the Perizzites, the Jebusites, the Ammonites, the Moabites, the Egyptians, and the Amorites - but have taken some of their daughters for wives. This action is portrayed as a violation of God's prohibition against intermarriage with the peoples of the land (cf. Deut. 7.1-3; 23.3). ${ }^{11}$ Following the advice of Shecaniah ben Jehiel, Ezra commands the people to put away these foreign wives and the children who had been born to them (10.3). Those who do not assemble in order to address this grave issue are themselves threatened with separation (בדל) from the congregation of Israel (10.8). In other words, those who will not separate themselves from their foreign wives and children will lose their connection to Israel. No mention is made of anything the foreign wives or their children can do to lessen or remove the offensiveness of these marriages, suggesting that the issue is not one that might be remedied by a change in moral or ritual behaviour. ${ }^{12}$ Instead, the only proper response is that the Israelite men separate themselves from these foreigners. 'While the women are charged with no crime, their husbands appear to be: they have caused foreigners to dwell... within the community, and that has endangered the community's existence' ${ }^{13}$ No opportunity is given for conversion, leading to the conclusion 'that the community here regards itself as racially distinct from its neighbors'. ${ }^{14}$

11. On the interweaving of these passages to create a complete ban on exogamy, see Jacob Milgrom, Cult and Conscience: The Asham and the Priestly Doctrine of Repentance (SJLA, 18; Leiden: Brill, 1976), pp. 71-73, idem, 'Religious Conversion and the Revolt Model for the Formation of Israel', JBL 101 (1982), pp. 169-76 (172), and Michael Fishbane, Biblical Interpretation in Ancient Israel (Oxford: Oxford University Press, 1985), pp. 114-23. As Thomas Willi, 'Leviten, Priester und Kult in vorhellenistischer Zeit: Die chronistische Optik in ihrem geschichtlichen Kontext', in Beate Ego, Armin Lange, and Peter Pilhofer (eds.), Gemeinde ohne Tempel_Community without Temple: Zur Substituierung und Transformation des Jerusalemer Tempels und seines Kults im Alten Testament, antiken Judentum und frühen Christentum (WUNT, 118; Tübingen: Mohr Siebeck, 1999), pp. 75-98 (86-87), states: "Bezugsgröße ist die Schrift als Einheit und Ganzheit, nicht eine bestimmte Fundstelle oder Textpassage' (emphasis original).

12. Myers, Ezra-Nehemiah, p. 84, states that 'Ezra-Nehemiah grapples with the marriage of Jews with unconverted people', thus distinguishing it from the book of Ruth where Ruth has already been converted. This is a strained interpretation of the passage, since neither wives nor children are ever given the opportunity to convert. As Morton Smith, Palestinian Parties and Politics that Shaped the Old Testament (London: SCM Press, 1987), p. 137, has argued: 'That the aliens involved in the mixed marriages might become proselytes - that is, might accept the obligations of the law and also receive its benefits, including purification - was something Ezra never considered'.

13. Janzen, Witch-hunts, p. 37.

14. Williamson, Ezra, Nehemiah, p. 132. So too Blenkinsopp, Ezra-Nehemiah, p. 176, and Hannah K. Harrington, 'Holiness and Purity in Ezra-Nehemiah', in Mark J. Boda and Paul L. Redditt (eds.), Unity and Disunity in Ezra-Nehemiah: Redaction, Rhetoric, and Reader (Hebrew Bible Monographs, 17; Sheffield: Sheffield Phoenix Press, 2008), pp. 98-116. 
Why then does Ezra-Nehemiah focus only on those men who had taken foreign wives, and not on those women who had been given as wives to foreign men? Presumably those women who had been given to foreign men had already left the congregation of Israel; Ezra cannot address them since they fall outside the boundaries of Israel. On the other hand, Israelite men who had married foreign women presumably required that these women worship YHWH; therefore, the intermarrying Israelite men were still within the boundaries of Israel and were guilty of attempting to bring their foreign wives into the community. ${ }^{15}$ Ezra attacks behaviour that evidences the belief that the borders surrounding Israel were permeable. As seen in the genealogies of Ezra 2, Israelite identity was constituted by genealogical descent from those who had been in captivity in Babylon. Attempting to bring others inside the boundaries of the community rendered the community itself impure; therefore, the only cure for this pollution was the removal of the outsiders.

One final piece of evidence for a genealogical definition of Israelite identity in Ezra-Nehemiah can be found in Ezra 9.2 (cf. Neh. 9.2). According to the accusation found in Ezra 9.2, through intermarriage the holy seed (זרע הקדש) of Israel had become mixed with the foreign nations. This holy seed imagery signifies the ontological distinction between Israel (holy seed) and the nations (common or profane seed) which could not be overcome. ${ }^{16}$ On the basis of such texts, Ezra-Nehemiah has rightly gained a reputation for being a work that promotes an exclusivistic definition of Israel. Christine E. Hayes's summary is apt:

Gentiles by definition and without exception are profane seed-permanently and irreparably - and marriage with them profanes the holy seed of Israel... In short, unlike the Pentateuch's moral-religious rationale for prohibitions of intermarriage, the holy seed rationale of Ezra supports a universal and permanent (i.e., transgenerational) prohibition on intermarriage. The holy seed rationale constructs an entirely impermeable boundary between Jew and Gentile. ${ }^{17}$

15. With Eskenazi and Judd, 'Marriage to a Stranger', p. 267, I believe that the prohibition would have applied to both men and women, but that factors such as 'Sex-ratio imbalance and greater control over women's marriage choices may explain the absence of reports about such violations by Judahite women'. On the disproportionate numbers of men to women among the Golah group, see Joel Weinberg, The Citizen-Temple Community (trans. Daniel L. Smith-Christopher; JSOTSup, 151; Sheffield: Sheffield Academic Press, 1992), pp. 42-43.

16. The only other occurrence of the phrase זרע קדש is found in Isa. 6.13. This same use of זרע can be found in Neh. 9.2, of which Williamson, Ezra, Nehemiah, p. 311, states: 'Its exclusively racial understanding of "Israel" is made clear by the use of זרע "seed"... and by the separation from "all foreigners" without distinction'.

17. Christine B. Hayes, Gentile Impurities and Jewish Identities: Intermarriage and Conversion from the Bible to the Talmud (Oxford: Oxford University Press, 2002), p. 32. This impenetrable border between Jew and Gentile constructed by Ezra-Nehemiah has also been noted by Jonathan Klawans, Impurity and Sin in Ancient Judaism (Oxford: Oxford University Press, 2000), pp. 43-46, and Harrington, 'Holiness and Purity'. 


\section{The Argument for Inclusive Strategies within Ezra-Nehemiah}

In spite of this evidence for exclusivism in Ezra-Nehemiah, some have called into question this reading of Ezra-Nehemiah. Upon reviewing the exclusivist thinking found within the work, Japhet states, 'The demand for complete separation, reiterated again and again in Ezr.-Neh., raises a further question: are the borders between the people of Israel and the nations eternally closed? Is there no way of joining the people of Israel? In other words: is there any possibility of conversion?' ${ }^{18}$ Japhet points to two passages, Ezra 6.21 and Neh. 10.29, to demonstrate the presence of a more inclusive definition of Israel at work within Ezra-Nehemiah. Since both of these passages refer to a group of people who separated themselves from (ובל הנבדל מן) the peoples of the land(s), and since these are the only occurrences of the phrase in the Hebrew Bible, it is likely that they can be understood in light of one another. We will therefore begin with Ezra 6.21, which states:

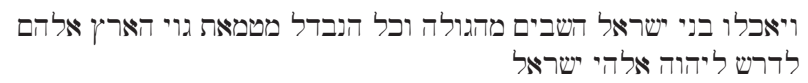

All the major English translations of the passage are similar to the RSv translation: '[I]t was eaten by the people of Israel who had returned from exile, and also by every one who had joined them and separated himself from the pollutions of the peoples of the land to worship the LoRD, the God of Israel' ${ }^{19}$ These translations portray two different groups partaking in the Passover meal: the Golah group and those who separated themselves from the peoples of the land. Despite this unanimity among the translations, the text is not so unambiguous; for instance, when comparing these translations to the MT, it is striking that a number of them supply the verb 'join' (e.g. RSV, NSAB, JSB, and NJB), a word that lacks an equivalent in either the MT or the LXX. ${ }^{20}$ Further, some translations contain the phrase 'together with', which again suggests two different groups (e.g. TNIV and JSB). I presume that it is the phrase אלהם, understood by these translations to mean 'with them', which is taken to support the interpretation that two separate groups are portrayed: the Golah group, and with them all who separated themselves from the impurity of the nations. Yet, while the preposition can

18. Japhet, 'People and Land', p. 117.

19. Such renderings are not unique to English translations, as a survey of German and French translations indicates.

20. Many commentaries similarly supply the word 'join'. As far as I have seen, that this is an addition to the text is noted only by Daniel L. Smith-Christopher, 'Between Ezra and Isaiah: Exclusion, Transformation, and Inclusion of the "Foreigner" in PostExilic Biblical Theology', in Mark G. Brett (ed.), Ethnicity in the Bible (BIS, 19; Leiden: E.J. Brill, 1996), pp. 117-42 (139 n. 53), who states: 'The salient phrase "all who joined them" is not specifically clear in either the Greek or Hebrew texts'. 
indeed bear the meaning 'with', ${ }^{21}$ one must still ask whether or not there is evidence that Ezra-Nehemiah elsewhere uses with this sense. The answer is no; the preposition occurs seventy times within the work, but does not once bear the meaning of 'with'. As a result, there is good reason to question this translation of אלהם in Ezra 6.21. If we were to omit these two interpretive additions to the text on the basis that they might be over-determinations, the resulting translation of Ezra 6.21 would not necessarily be substantially different in meaning: 'All the sons of Israel who returned from the exile and those who separated themselves from the impurity of the nations of the land to them to seek Yнwн the God of Israel, ate'. To be sure, this is a rather awkward construction, since it is difficult to identify what is meant by the phrase 'to them'; nevertheless, the sentence retains its awkwardness regardless of how it is translated.

On the basis of translations such as those noted above, scholars have concluded that 6.19-21 presents evidence of a greater openness to Gentiles than is found elsewhere in Ezra-Nehemiah. Thus, John Kessler states that 'the exclusivist text of Ezra-Nehemiah bears witness to subtle inclusivist strategies'. ${ }^{22}$ In particular, he points to Ezra 6.21, 'where participation in the Passover is open not only to the Golah group but to all who purify themselves from the uncleanness of the surrounding nations' ${ }^{23}$ L.H. Brockington, in an attempt to define this group more closely, suggests that this passage envisions the celebration of the Passover, at the very least by Jews who have not been in exile, ${ }^{24}$ and quite possibly by proselytes from the surrounding peoples. ${ }^{25}$

While a few scholars favour a limited inclusivism, which applies only to those who are Jews but have not been exiled, the vast majority believes that the group described here refers to proselytes to Judaism. Thus, Jacob M. Myers states: 'The participants were members of the golah, priests, Levites, and those who had absolved themselves of the impurities of the people of the land in order

21. Cf. Ronald J. Williams, Hebrew Syntax: An Outline (Toronto: University of Toronto Press, 2nd edn, 1976), §304. The Lxx translates with mpós, which can also, at times, be translated as 'with'. See T. Muraoka, A Greek-English Lexicon of the Septuagint (Chiefly of the Pentateuch and Twelve Prophets) (Louvain: Peeters, 2002), p. 485.

22. John Kessler, 'Persia's Loyal Yahwists: Power Identity and Ethnicity in Achaemenid Yehud', in Oded Lipschits and Manfred Oeming (eds.), Judah and the Judaeans in the Persian Period (Winona Lake, IN: Eisenbrauns, 2006), pp. 91-121 (109).

23. Kessler, 'Persia's Loyal Yahwists', p. 109.

24. This interpretation is shared by Heinrich Schneider, Die Bücher Esdras und Nehemia (HSAT, 4.2; Bonn: Peter Hanstein, 1959), p. 128; Wilhelm Rudolph, Esra und Nehemia samt 3. Esra (HAT, 20; Tübingen: Mohr [Siebeck], 1949), p. 64; Smith, Palestinian Parties, p. 214 n. 167; Mervin Breneman, Ezra, Nehemiah, Esther (NAC, 10; Nashville: Broadman \& Holman, 1993), p. 121; and Joseph Fleishman, 'An Echo of Optimism in Ezra 6:19-22', HUCA 69 (1998), pp. 15-29.

25. L.H. Brockington, Ezra, Nehemiah and Esther (NCBC; Greenwood: Attic Press, 1969), p. 86. 
to join Israel, that is, proselytes' ${ }^{26}$ As noted, on the basis of this interpretation of Ezra 6.21, most scholars have called into question the exclusivistic picture painted of Ezra-Nehemiah. For instance, H.G.M. Williamson claims that Ezra 6.21 is evidence 'that there were different avenues into the community at this time'. ${ }^{27}$ Similarly, Joseph Blenkinsopp concludes that 'their inclusion illustrates the openness of the postexilic Jewish community to outsiders who wished to become insiders'. ${ }^{28}$ And Japhet states: 'The description of these people is an excellent definition of religious conversion: joining a new community for the sake of its faith and religious way of life, as outlined by its laws' ${ }^{29}$ The belief that Ezra 6.21 envisions the entrance of proselytes into the community is also found in pre-critical exegesis, as seen in Rashi's discussion of $b$. Kiddushin $70 \mathrm{a},{ }^{30}$ as well as the commentary on Ezra and Nehemiah by the seventh-century CE Christian scholar Bede. ${ }^{31}$

\section{A Challenge to the Inclusivist Reading of Ezra 6.19-21}

If this interpretation of Ezra 6.19-21 is correct, there is a startling difference in views with regard to who could belong to the community of Israel within Ezra-Nehemiah. ${ }^{32}$ In contrast to much of the work, which is clearly opposed to the entrance of non-returnees into the community, the dominant interpretation of 6.19-21 indicates a willingness to allow either Judaeans, who have not been exiled, or even Gentiles, who have separated themselves from their former

26. Myers, Ezra-Nehemiah, p. 54. So too Clines, Ezra, p. 97; F. Charles Fensham, The Books of Ezra and Nehemiah (Grand Rapids: Eerdmans, 1982), p. 96; Blenkinsopp, Ezra-Nehemiah, pp. 132-33; Williamson, Ezra, Nehemiah, p. 85; and Anna L. GrantHenderson, Inclusive Voices in Post-exilic Judah (Collegeville: Liturgical Press, 2002), p. 122.

27. Williamson, Ezra, Nehemiah, p. 36.

28. Blenkinsopp, Ezra-Nehemiah, p. 133.

29. Japhet, 'People and Land', p. 117.

30. Cf. Yosef Rabinowitz, The Book of Ezra: A New Translation with a Commentary Anthologized from Talmudic, Midrashic, and Rabbinic Sources (Artscroll Tanach Series; Brooklyn: Mesorah Press, 1984), p. 150.

31. Bede, On Ezra and Nehemiah, Book 2: 'This can also be rightly understood in connection with proselytes, who, though they were Gentiles by nature, were converted to the religious custom of God's people after accepting circumcision and having been cleansed through the legally prescribed offerings, in order that they also would be worthy to participate in the saving sacrifice'. Translation is that of Scott DeGregorio, Bede: On Ezra and Nehemiah (Translated Texts for Historians, 47; Liverpool: Liverpool University Press, 2006), p. 105.

32. As Mark J. Boda, Praying the Tradition: The Origin and Use of Tradition in Nehemiah 9 (BZAW, 277; Berlin: Walter de Gruyter, 1999), p. 192 n. 17, states: 'This is a surprising piece of information in a section of Ezr-Neh that elsewhere portrays no other Jewish community than that which returned from Mesopotamia'. 
practices and adopted Jewish practices, to enter into the boundaries of the community. ${ }^{33}$

That 6.19-21 seems to contradict a central ideological concern of the rest of Ezra-Nehemiah should provoke a willingness to see whether the text can be interpreted differently. If those who separated themselves from the impurity of the nations could become part of the community, why would Ezra 2.59-63 evidence such a concern about the lack of genealogical records for certain families? Why not simply inquire into the family's fidelity to YHWH? ${ }^{34}$ Why were the non-returnees who claimed to seek YHWH not permitted to join in the rebuilding of the Temple in 4.1-3, if in 6.21 they could celebrate the Passover? Should not such contradictions cause interpreters to wonder whether they have understood both passages correctly? While it is possible that Ezra-Nehemiah contradicts itself, it is improbable that it would do so on a concern that is integral to the very purpose of its composition. Perhaps the apparent contradiction between Ezra 6.19-21 and the rest of Ezra-Nehemiah can be resolved by a different translation of Ezra 6.19-21. Despite the fact that virtually all recent translations provide an inclusive reading of Ezra 6.21, the realization that these translations lead to an understanding of 6.19-21 that flies in the face of the theology of the rest of Ezra-Nehemiah should compel commentators to reinterpret this verse. ${ }^{35}$

Again, the Hebrew of Ezra 6.21 is as follows:

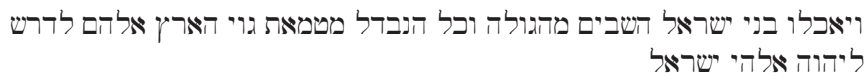

In the remainder of this paper, I will argue that modern translations of 6.21 are erroneous in that they interpret the waw immediately preceding the phrase בל הנבדל מטמאת גוי הארץ as a simple coordinative waw; instead, the conjunction ought to be understood as a waw explicativum or epexegetical waw. Most commentators and translations render the Hebrew of 6.21 in roughly the following way: 'And all the sons of Israel, who had returned from exile, and all who

33. It is important to acknowledge that scholars have generally divided EzraNehemiah into discrete units of material; cf. Blenkinsopp, Ezra-Nehemiah, pp. 41-47, and Williamson, Ezra, Nehemiah, pp. xxiii-xxxv. Nonetheless, since Ezra 1-6 is traditionally viewed as a self-contained unit, two of the passages evidencing exclusivistic thinking occur in the same source as Ezra 6.21. Olyan, 'Purity Ideology', p. 14, concludes that all the sources of Ezra-Nehemiah 'share an anti-alien perspective, [but] articulate their opposition to aliens and to intermarriage in slightly different ways'.

34. Although Japhet, 'People and Land', p. 114, argues that the genealogies of Ezra 2 and Neh. 7 do in fact incorporate non-returnees into Israel, the point of these lists is to demonstrate the overwhelming importance of having an impeccable genealogy.

35. Janzen, Witch-hunts, p. 95, is the only interpreter who understands the clause, 'all those who had separated themselves from the uncleanness of the nations of the land', as a reference to the returnees. In a recent article ('The Cries of Jerusalem: Ethnic, Cultic, Legal, and Geographic Boundaries in Ezra-Nehemiah', in Boda and Redditt [eds.], Unity and Disunity in Ezra-Nehemiah, pp. 117-35 [125-26 n. 28]), Janzen states that it is the overall exclusivism of Ezra-Nehemiah which leads him to this interpretation of the waw. 
separated themselves from the impurity of the nations of the land, ate...' In contrast, I am suggesting that the following translation captures more accurately, albeit for the moment more opaquely, the intended meaning: 'And all the sons of Israel who had returned from exile, that is, those who had separated themselves from the impurity of the nations of the land to them ${ }^{36}$ to seek Yнwн God of Israel, ate...'

Evidence that the waw can function epexegetically can be found in the standard Hebrew grammars and dictionaries. ${ }^{37}$ Bruce K. Waltke and M. O'Connor claim: 'Waw may stand before clauses which serve to clarify or specify the sense of the preceding clause' ${ }^{38}$ Similarly, Bill T. Arnold and John H. Choi state that the waw explicativum 'introduces a clause or phrase that clarifies, expands, or paraphrases the clause that precedes it'. ${ }^{39}$ An example of the waw explicativum from outside of Ezra-Nehemiah illustrates this use of the waw nicely. 1 Sam. 17.40 states of the five smooth stones with which David kills Goliath: (literally, 'And he set them [i.e. the stones] in his shepherd's vessel and in the pouch'). Clearly David did not set the stones in both his shepherd's vessel and in his pouch; rather, he set them in his shepherd's vessel, that is, in his pouch.

This use of the waw is fairly common in OT literature, as the grammars make apparent, ${ }^{40}$ but is there any evidence of the use of the explicative waw within Ezra-Nehemiah itself? Ezra 6.9 is an uncontroversial example of the explicative waw in Ezra-Nehemiah: ומה חשחן ובני תורין ודכרין ואמרין לעלון לאלה "Ast. The English rendering of the Aramaic is as follows: 'And whatever is neededwhether young bulls or rams or sheep-for offering to God...' The waw immediately preceding בני תורין clearly functions to explain what is meant by the phrase

36. Rudolph, Esra und Nehemia, p. 64, calls the phrase אלהם a 'prägnante Konstruktion'. Significantly, 1 Esd. 7.13, the Peshitta, and the Ethiopic all omit any equivalent to אלהם, showing that ancient interpreters also found it difficult to make intelligible sense of this phrase. I will clarify below how this phrase fits within the sentence.

37. See BDB, p. 252; GKC §154a; Williams, Hebrew Syntax, §434; C.H.J van der Merwe, et al., A Biblical Hebrew Reference Grammar (Sheffield: Sheffield Academic Press, 1999), §40.8.2 (vii); Bill T. Arnold and John H. Choi, A Guide to Biblical Hebrew Syntax (Cambridge: Cambridge University Press, 2003), §4.3.3(d); and Bruce K. Waltke and M. O'Connor, An Introduction to Biblical Hebrew Syntax (Winona Lake, IN: Eisenbrauns, 1990), §39.2.4.

38. Waltke and O'Connor, Introduction, §39.2.4.

39. Arnold and Choi, Guide, p. 147.

40. In addition to these standard grammars, see also David W. Baker, 'Further Examples of the Waw Explicativum', VT 30 (1980), pp. 129-36, and Patrick Wilton, 'More Cases of Waw Explicativum', VT 44 (1994), pp. 125-28. Although Richard C. Steiner, 'Does the Biblical Hebrew Conjunction - ו- Have Many Meanings, One Meaning, or No Meaning at All?', JBL 119 (2000), pp. 249-67, argues against the numerous purported uses of waw, his conclusion that waw either means 'and' or is meaningless could be used to support my interpretation of this passage if the waw here is meaningless and the clause merely stands in apposition to the clause which precedes it. 
海 explicative waw, albeit, in Aramaic. An example of the explicative waw from the Hebrew portions of the work can be found in Ezra 8.18, where it is said: 'And they brought to us, by the good hand of God upon us, a man of understanding from the sons of Mahli, the son of Levi, the son of Israel, namely Sherebiah' (מבני מחלי בן־לוי בן־ישראל ושרביה). tions of Ezra-Nehemiah, then, we see that it is possible that waw can function as an explicative waw, demonstrating the possibility that the waw in 6.21 might also function epexegetically.

Admittedly, to make the case that the waw of 6.21 could be interpreted as a waw explicativum is not the same as demonstrating good reasons for why it should be interpreted in this way. Apart from the fact that the standard interpretations of 6.19-21 contradict the rest of Ezra-Nehemiah, do we have a compelling basis within the context of 6.19-21 to argue that this waw ought to be interpreted in this manner? Evidence within the verse immediately preceding 6.21 provides a compelling reason to interpret the phrase following this waw as an explication of the clauses preceding it. Ezra 6.20 describes the preparation of the Passover feast: 'For the priests and the Levites purified themselves (טהר) together-all of them were pure (טהור). And they killed the Passover lamb for all the sons of the Golah, and for their fellow priests, and for themselves.' According to v. 20, therefore, the Passover lamb was slaughtered for three groups of people - those priests and Levites who had slaughtered the lamb, their fellow priests, and the returnees to the land. Given this explicit delimitation of those for whom the Passover festival was prepared, we should expect the list of those who celebrate the Passover in 6.21 to match this group of people. Since no mention is made of non-returnees or proselytes partaking in the Passover in 6.20, it is best to see 6.21 as an elaboration and description of the three groups in 6.20, not a contradictory list of those participating in the Passover. ${ }^{43}$ In other words, the list of people in 6.20 ought to guide our

41. So too Charles C. Torrey, Ezra Studies (New York: Ktav, 1970), p. 194. With regard to the explicative waw, Torrey states: "An explicative ', meaning "even" or "namely", was certainly used to a considerable extent in the Aramaic of this period'. Significantly, the explicative use of the waw in a verse within Ezra 1-6, a passage which source critics believe to be unified, suggests that whoever authored this passage did make use of this function of the waw.

42. Torrey, Ezra Studies, p. 265.

43. Antonius H.J. Gunneweg, Esra (KAT, 1/1; Gütersloh: Gerd Mohn, 1985), pp. 114-17; Dieter Böhler, Die heilige Stadt in Esdras a und Esra-Nehemia: Zwei Konzeptionen der Weiderherstellung Israels (OBO, 158; Göttingen: Vandenhoeck \& Ruprecht, 1997), p. 386 n. 259; and Juha Pakkala, Ezra the Scribe: The Development of Ezra 7-10 and Nehemia 8 (BZAW, 347; Berlin: Walter de Gruyter, 2004), pp. 69-73, seeing the contradiction between v. 20 and v. 21 , believe 6.21 to be a later, more inclusive correction to the original story of 6.19-20,22. The difficulty with this interpretation, apart from its speculative nature, is that it fails to explain why this later editor did not make an inclusivistic correction in 6.20 as well. 
interpretation of 6.21. If we allow 6.20 to aid us, we are led quite naturally to the conclusion that the waw in 6.21 is an explicative waw. The returnees from the Babylonian Exile are those who have separated themselves from the impurity of the nations of the land. Ezra 6.21 should not be translated in order to suggest two different groups (those who returned from exile and those who separated themselves from the impurity of the nations), but rather as two descriptions of the same group, the latter clause, beginning with a waw explicativum or epexegetical waw, further clarifying the identity of those mentioned in the former clause: 'And all the sons of Israel who returned from the exile, that is, all who had kept themselves separate from the impurity of the nations to them to seek Yнwн God of Israel, ate...'

Further internal evidence that this reading is to be preferred can be found in the function of the awkward אלהם within the sentence. As noted above, most commentators and translators appear to translate אמבר as 'with', yet this meaning is not attested by any of the other occurrences of the preposition in EzraNehemiah. It therefore appears preferable to translate the phrase as 'to them', given that the vast majority of occurrences of within the work mean 'to'. But how do we then make sense of the verse? The answer lies in the fact that the niphal of בדל often connotes two movements - movement away from one thing and movement toward another thing. This dual movement is often represented by the verb מדל (demarcating separation from), and (demarcating separation toward). For instance, in Lev. 20.26 Yhwh says to Israel: ואבדל אתכם מן העמים להיות לי לי לי ('And I will separate you from the peoples to be to me'). ${ }^{44}$ Ezra-Nehemiah modifies this construction ever so slightly by switching the preposition $ל$ with the preposition clearly in Neh. 10.29: כל הנבדל מעמי הארצות אל תורת האלהים ('all who separated themselves from the peoples of the lands to the Torah of God'). In fact, in light of Neh. 10.29, the difficulty surrounding Ezra 6.21 becomes significantly more straightforward: 'All who separated themselves from the impurity of the peoples of the land (separated) to them to seek Yнwh, the God of Israel'. In other words, just as in Neh. 10.29, where there is a separation from the peoples that is simultaneously a separation toward the Torah, so in Ezra 6.21, there is a separation from the peoples that is simultaneously a separation toward a group referred to by the pronoun 'them'.

But who is the antecedent of the third person plural pronoun? If the waw preceding the clause is a coordinating conjunction, the pronoun could refer to the sons of the Golah; indeed, most commentators have interpreted the pronoun in this way. Since the argument being made here is that the waw is epexegetical, the pronoun cannot refer to this group. So to whom does it refer? ${ }^{45}$ The only group to whom the pronoun can refer is the priests who have prepared the Passover in

44. For similar constructions, see Num. 8.14; 16.9; Deut. 29.20; and 1 Kgs 8.53.

45. This question is raised of Janzen's interpretation by H.G.M. Williamson, 'More Unity than Diversity', in Boda and Redditt (eds.), Unity and Disunity in Ezra-Nehemiah, pp. 329-43 (335-36). 
v. $20 .{ }^{46}$ One result of this identification of the pronoun is that it appears to confirm that it is the Golah group that joins itself from the טמאה of the peoples of the land, and simultaneously separates itself to the טהור of the priests by taking part in the Passover. The juxtaposition of the words טהור/טמרה occurs frequently throughout the Old Testament, since Israel is to distinguish (בדל) between the holy and the profane, the impure (טמה (טהור) and the pure (Lev. 10.10). ${ }^{47}$ On this reading, Ezra 6.21 pictures the Golah group as both separating from the impurity of the peoples and separating to the purity of the priests in their celebration of Passover, a portrayal that is consistent with the theological concerns of the work. To paraphrase Ezra 6.21: The Golah group is described as consisting of those who have simultaneously separated themselves from the impurity of the peoples of the land and separated themselves to the priests to seek Yнwн, the God of Israel.

One final piece of evidence can be marshaled to support the claim that the waw ought to be read as a waw explicativum; namely, this understanding appears in a number of our earliest translations of Ezra 6.21. The Lxx to Ezra 6.21 (i.e. Esdras

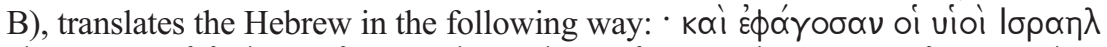

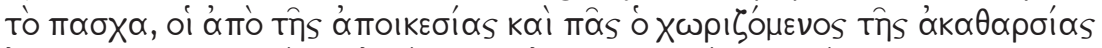

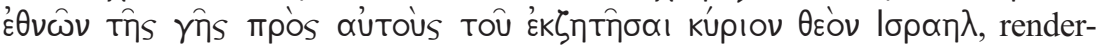
ing the waw with kaí. ${ }^{48}$ This translation unfortunately clarifies nothing for us, since the Greek conjunction kói, just like waw, can function epexegetically. ${ }^{49}$ Nonetheless, 1 Esd. 7.13 (i.e. Esdras A) possibly demonstrates that some ancient readers did in fact understand the waw as prefacing an explicative phrase, since it does not render the waw of Ezra 6.21 with any Greek equivalent: kai है $\sigma \alpha \gamma_{\gamma} \sigma \sigma \alpha v$

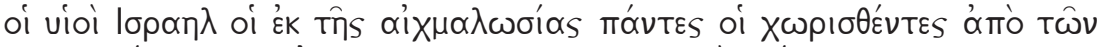

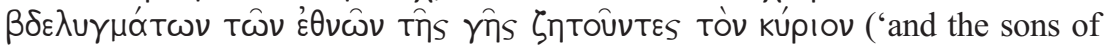
Israel, those who came from captivity, all those who had separated themselves from the abominations of the nations of the land and sought the Lord, ate').$^{50}$

46. I am thankful to Andrea di Giovanni for this exegetical insight, as well as for making available to me a copy of her unpublished paper, entitled 'Separation Anxiety: An Analysis of the Term $b d l$ in Ezra-Nehemiah', which was presented at the Canadian Society of Biblical Studies/Société canadienne des Études bibliques Annual Meeting, Vancouver, BC (1 June, 2008).

47. Other instances where these words are juxtaposed are Lev. 7.19; 11.32, 36, 47; $13.59 ; 14.19 ; 15.8 ; 16.19 ; 17.15 ; 20.25 ; 22.4$; Num. 5.28; 19.19; Deut. 12.15, 22; 15.22; Ezek. 22.26; 24.13; 36.25; 37.23; 44.23; Job 14.4; Eccl. 9.2; 2 Chron. 29.16.

48. Cf. Robert Hanhart (ed.), Esdrae liber II (Septuaginta, 8.2; Göttingen: Vandenhoeck \& Ruprecht, 1993), p. 108.

49. See Muraoka, Greek-English Lexicon, p. 282, as well as BDF $\S 442$ (9), and Daniel B. Wallace, Greek Grammar Beyond the Basics: An Exegetical Syntax of the New Testament (Grand Rapids: Zondervan, 1996), p. 673.

50. The manuscript tradition of 1 Esdras almost unanimously lacks k $\alpha i$ or any other conjunction, the exception being the $\alpha$-text, as seen in Robert Hanhart (ed.), Esdrae liber I (Septuaginta, 8.1; Göttingen: Vandenhoeck \& Ruprecht, 1974), p. 115, and Zipora Talshir, I Esdras: A Text Critical Commentary (SBLSCSS, 50; Atlanta: SBL Press, 2001), p. 383. Note again that 1 Esdras also omits any equivalent to the awkward אלדם. 
While there is uncertainty about whether 1 Esdras is an independent translation of the Hebrew and Aramaic, or a compilation from a prior Greek translation of Chronicles, Ezra, and Nehemiah, ${ }^{51} 1$ Esd. 7.13 provides evidence that either the author or a previous translator of Ezra 6.21 may have believed that the waw preceding the phrase כל הנבדל functioned in an explicative manner and therefore thought it permissible to omit the conjunction without in any way changing the meaning of the passage. ${ }^{52}$ This is not surprising since, as Zipora Talshir has noted, 'The translator of I Esd would have had little compunction when it came to dealing with something as minor as a $w_{a w}{ }^{53}$ Nonetheless, Talshir believes that there are times when the omission of a waw dramatically changes the meaning of a text, turning 'two categories into one'. ${ }^{54}$ This, she believes, has occurred in 1 Esd. 7.13. But has it? While this possibility cannot be entirely excluded, is there not just as strong a possibility that the translator, or his Vorlage, read the waw of Ezra 6.21 as an epexegetical waw, and therefore omitted it for the sake of clarity?

In light of the overwhelming evidence of exclusion in Ezra-Nehemiah, the onus of proof should be on those who believe that Ezra 6.21 envisions a contrasting openness to foreigners. The only evidence cited for this interpretation is that Exod. 12.48-49 and Num. 9.14 both envision the presence of the nonIsraelite גat at the celebration of the Passover. ${ }^{55}$ But these passages are not sufficient to demonstrate that Ezra-Nehemiah also permitted גרים to celebrate the Passover, since it is quite conceivable that the author of Ezra-Nehemiah did not know of this legislation, ${ }^{56}$ or, if he did, did not approve of such openness. ${ }^{57}$ Since no satisfactory argumentation has been provided for this interpretation, and since the list of those who are to eat of the Passover lamb is explicitly restricted to priests and those who returned from the exile (6.20), it is preferable to understand those who separate themselves from the nations as a description of the returnees.

51. Otto Eissfeldt, The Old Testament: An Introduction (trans. Peter R. Ackroyd; New York: Harper \& Row, 1965), p. 575, believes it more likely that the author translated the Hebrew/Aramaic himself, while H.St.J. Thackeray, 'The First Book of Esdras', in J. Hastings (ed.), A Dictionary of the Bible (New York: Charles Scribner's Sons, 1899), pp. 758-63, believes it more likely the author availed himself of a prior Greek translation.

52. In addition to 1 Esdras, the Ethiopic and Peshitta also omit the waw.

53. Zipora Talshir, I Esdras: From Origin to Translation (SBLSCSS, 47; Atlanta: SBL Press, 1999), p. 191.

54. Talshir, From Origin to Translation, p. 192.

55. Cf., for instance, Clines, Ezra, p. 97, and Fensham, Ezra, Nehemiah, p. 96.

56. Presumably the category of the גas unknown to or contested by EzraNehemiah, since the word does not occur in the work.

57. For instance, Mary Douglas, In the Wilderness: The Doctrine of Defilement in the Book of Numbers (JSOTSup, 158; Sheffield: Sheffield Academic Press, 1993), and Jacob's Tears: The Priestly Work of Reconciliation (Oxford: Oxford University Press, 2004), has argued that the priestly writings contest the exclusiveness of Ezra-Nehemiah. 


\section{Nehemiah 10.29-30 in Light of Ezra 6.19-21}

The interpretation of Ezra 6.21 provided above sheds light on the similar phrase found in Neh. 10.29-30 (EV 10.28-29). Like Ezra 6.19-22, Neh. 10.29-30 has been interpreted to demonstrate that the work evidences an openness toward foreigners. ${ }^{58}$ Again, the people of Israel are described by a list which the RSV translates in the following way: 'The rest of the people, the priests, the Levites, the gatekeepers, the singers, the temple servants, ${ }^{59}$ and all those who had separated themselves from the peoples of the lands (וכל הנברל מעמי הארצות) to the law of God...' Most commentators make use of a translation similar to that of the RSv, yet, given the similarity in phrasing, Neh. 10.29-30 ought to be understood in light of Ezra 6.19-21, and therefore the phrase should again be seen as a description of the returnees, not as a reference to a different group. And, in fact, Clines intuits this interpretive possibility, acknowledging that the phrase 'all those who have separated themselves...' could be 'a way of describing the people as a whole' (though he immediately dismisses this suggestion without explicit justification). ${ }^{60}$ As in Ezra 6.19-22, the waw of Neh. 10.29 should be interpreted as an explicative waw; the clause 'Everyone who separated from the peoples of the lands to the Torah of God' describes the congregation, not a distinct group of proselytes, since the work consistently exhibits exclusionary thinking with regard to foreigners. While the context does not aid in the interpretation of Neh. 10.20 in the way that Ezra 6.20 did for 6.21, the passage also lacks the admittedly ambiguous אלהם found in Ezra 6.21. Further, two ancient manuscripts of Nehemiah, $\mathrm{L}^{123}$ and Aeth $^{-\mathrm{B}}$, omit the equivalent of the waw preceding the clause ובל הנבדל מעמי הארצות, thus placing it in apposition to the prior list of people. ${ }^{61}$ Therefore, Neh. 10.29 should be translated in the following way: 'And the rest of the people, the priests, the Levites, the gate-keepers, the singers, the temple servants, that is, all who had separated themselves from the peoples of the lands to the Torah of God...'

\section{Conclusion}

Ezra-Nehemiah evidences strong genealogical exclusionary thinking, in which Israel is distinguished from all other nations. The requirements to divorce foreign wives and abandon the children of mixed marriages indicate that the only solution to the impurity that resulted was radical separation. The Israelite men, the foreign women, and the children of mixed marriages could seemingly avail themselves of no lesser remedy, such as conversion, ritual purification, or

58. Cf. Blenkinsopp, Ezra-Nehemiah, p. 314, and Clines, Ezra, p. 205.

59. On this group within Ezra-Nehemiah, see Weinberg, The Citizen-Temple Community, pp. 75-91.

60. Clines, Ezra, p. 205.

61. Cf. Hanhart, Esdrae liber II, p. 217. 
repentance. In other words, the portrayal of Israelite identity in Ezra-Nehemiah is thoroughly genealogical. The boundaries separating Israel from the nations are impermeable and countenance no trespassers. According to Ezra-Nehemiah, those who attempted to bring outsiders into the congregation of Israel endanger the whole community by bringing impurity into a place where only purity could exist. Ezra 6.19-21 and Neh. 10.29-30 should not be read against the grain of the entirety of Ezra-Nehemiah. These passages do not suggest a permeable boundary between Israelite and non-Israelite, but should instead be understood as further evidence for the genealogical distance thought to exist between these two people groups: Israel was the holy seed, all other nations were common seed, and the two were not to be mixed. Both passages portray the separation of the Golah group from the impurity of the peoples of the land to the purity of the priests and to the Torah, in obedience to God's command that Israel is to distinguish and separate the pure from the impure. 